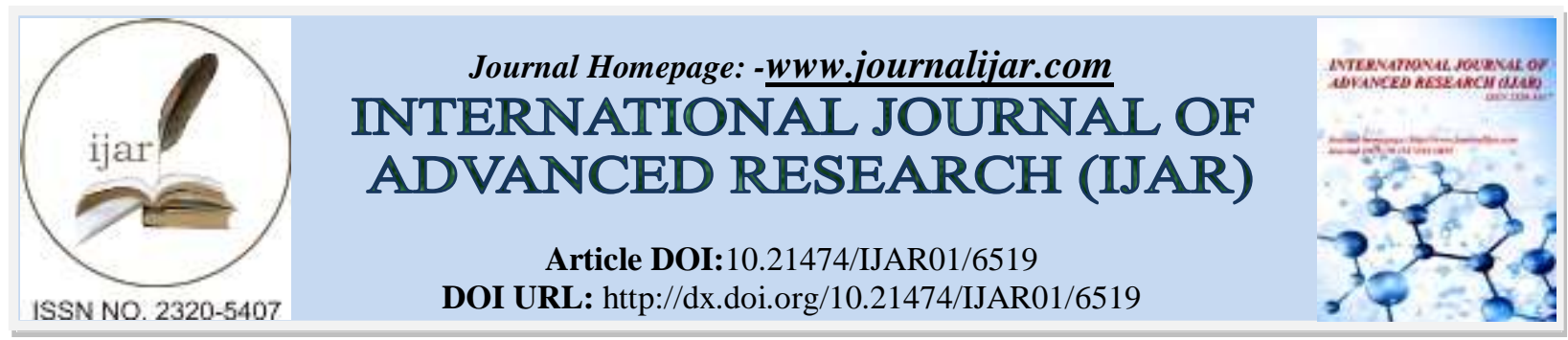

RESEARCH ARTICLE

\title{
THE EFFECT OF CAMEL MILK WHEY PROTEINS ON LACTIC ACID BACTERIA ISOLATED FROM CAMEL AND COW MILKS IN EGYPT: A COMPARATIVE STUDY.
}

Mariam Mohammed ${ }^{1}$, Marwa H.El-Gendy ${ }^{1}$, Aida S. Salem ${ }^{2}$ and Wafai Z. A. Mikhail ${ }^{3}$.

1. Animal Production Division, Desert Research Center, Cairo, Egypt.

2. Dairy Technology Department, Animal Production Research Institute, Agricultural Research Center, Giza, Egypt.

3. Department of Natural Resources,Instituteof African Research and Studies, Cairo University, Cairo, Egypt.

\section{Manuscript Info}

(.........................

Manuscript History

Received: 13 December 2017

Final Accepted: 15 January 2018

Published: February 2018

Key words:-

Camel milk, lactic acid bacteria, whey proteins

\section{Abstract}

Camel milk also has valuable nutritional properties as it contains a high proportion of antibacterial substances that found naturally in camel milk or derived by lactic acid bacteria .This study was carried out to evaluate the effect of camel's milk whey on lactic acid bacteria (LAB) isolated from cows' and camels' milk. Fifty-eight lactic acid bacteria species $(41,17$ isolates were obtained from camel milk and cow milk respectively) were isolated from 14 camel's milk samples and 5 samples of raw cow's milk and 2 samples of zabady were collected from different regions in Egypt and Sudan, followed by preidentification using phenotypic and genotypic methods using rep-PCR techniques. Then All LAB strains isolated from both camel's and cow's milk were examined to grow at constant concentration of whey camel's milk and its ability to grow was determined as optical density during 24 hours. Based on phenotypic and genotypic identification, Lactobacilli isolates were identified as: Lb rhamnosus (8.6\%), Lb.fermentum (10.3\%), Lb.acidophilus (8.6\%), Lb. delbrueckii subsp. lactis( 7\%), Lb.plantarum (13.8\%). Among cocci isolates, Lc. lactis subsp.lactis were $13.8 \%$, Lc.garvieae were $1.7 \%$, Lc. lactis subsp. cremoris were $1.7 \%$, Enterococcus faecium were $27.6 \%$ and Streptococcus thermophilus were $5.2 \%$. Whereas, $1.7 \%$ of isolates were identified as Bidobacterium animalis. All LAB that isolated from camel's milk showed a good ability to grow at the concentration of whey $20 \%$ compared with those isolated from cow's milk.

Copy Right, IJAR, 2018,. All rights reserved.

\section{Introduction:-}

In the last decades, many studies have indicated that camel milk is an important food source because it has functional and healthy benefits due to the presence of biological substances active in it (Asres and Yusuf, 2014).

In Egypt, the majority of people consume cow's milk regularly than camel milk, due to the fact that cows and buffaloes give much more milk and require less maintenance and labor. Unfortunately, people are not aware about the nutritional facts and healthy benefits of camel's milk. Camel's milk is regarded to be abundant source of proteins for people living in arid lands of the world. These proteins are found with high concentration in the whey of camel 
milk and are rich in protective components include lysozyme, lactoferrin, lactoperoxidase (LP) and peptidoglycan recognition protein (PGRP) which only detected in camel's milk (Singh et al., 2006; Kappelr et al., 2004), IGA and IGg immunoglobulin's that are compatible with human ones and provide effective defense against several viral and bacterial pathogens (Khitam, 2003). Camel's milk consumption may also be helpful in reducing the nutritional deficiencies and morbidities in adult community (Agrawal, et al., 2005; Singh et al., 2009).

Lactic acid bacteria (LAB) are considered as a Gram positive, non-spore forming, catalase- negative and acid tolerant microorganisms that produce lactic acid as the primary end-produced during carbohydrate fermentation (Carr et al., 2002). (LAB) are one of the most important beneficial microbiota in camel milk, which is vitality of an important source for various dairy technology (Khedid, et al., 2009). LAB are among the important groups of bacteria providing health benefits to human, animal and plant (Song, et al., 2012). Using LAB in food is one of the ancient known food preserving techniques. LABs are widely spread. It was found in many different food products (dairy, meat, beverages and vegetables), but they are also present in the mouth, digestive system and vagina of mammals (Hayek and Ibrahim, 2013). Also LAB plays an important role in the food industry, as they are used for health improvement, production of macromolecules, enzymes and metabolites (Pfeiler and Kleinhammer, 2007).

Bacteria in general, require an appropriated biochemical and environment to grow and express normal metabolic activities. There are many factors that affect the growth of LAB strains, including those related to intrinsic the food itself (water activity; $\mathrm{pH}$ value; nutrient content; antimicrobial substances and mechanical barriers to microbial invasion; redox potential.), including extrinsic related to the environment (the temperature of storage; the atmosphere surrounding the food). Also, implicit factors are the factors related to the microorganisms themselves and processing factors. (Hamad, 2012,Hayek and Ibrahim, 2013).

Biochemical conditions including stimulatory, preferred, and essential nutrients have significant impact on the growth and studied throughout the world and it approved that camel's milk contains several antimicrobial agents including lactoferrin, lactoperoxidase, lysozyme and PGRP (Reiter, 1985; Renner, et al., 1989; Kappler, et al., 2004;) that found with high concentration in whey of camel's milk. The effect of this antimicrobial agent against pathogenic bacteria such as Escherichia coli and Rotavirus has been studied in several investigations but its effect on LAB is not clear till now. Furthermore, isolating and classifying this bacterial group from camel's milk and selecting them as starter cultures are important steps for the better use of camel's milk.

Thus, the aim of this investigation is to evaluate the effect of whey camel's milk (that is rich in antimicrobial proteins) on the behavior of lactic acid bacteria isolated from camel and cow's milk in parallel.

\section{Materials and Methods:- Sampling:-}

Total 14 samples of camel's milk and 5 samples of raw cow's milk and 2 samples of zabady (a traditional fermented product from cow milk) were collected from different regions in Egypt and Sudan. Camel's milk samples were collected from several regions in Egypt including; King Maryout (5 samples) and El Amrya (2 samples) at the Alexandria governorate; Matrouh (2 samples) andEl Omyed (2 samples)at the Marsa Matrouh governorate; Halayeb and Shalteen (1samples) at the New Valley governorate and one sample from north of Sudan. Samples of camel milk were collected at the same season (winter-spring for year 2015-2016) and milking was performed randomly during different periods ranging from one day to 3 months after parturition whereas, cow milk samples were collected from Alexandria governorate at the winter season. All samples were immediately cooled and transported to the laboratory in an icebox $\left(4{ }^{\circ} \mathrm{C}\right)$ and analyzed for the content of LAB on the arrival.

\section{Isolation of Lactic Acid Bacteria:-}

Thirty $\mathrm{ml}$ of each milk sample were incubated at $30^{\circ} \mathrm{C}$ (for mesophilic LAB), $42^{\circ} \mathrm{C}$ (for thermophilic LAB) and $37^{\circ} \mathrm{C}$ (Both LAB) until coagulation for 24 hours to facilitate their isolation. The cultures were streaked on different media included M17 agar (Biolife Italy) for lactococci, MRS agar (de Man et al., 1960) (for lactobacilli) at $30^{\circ} \mathrm{C}, 37^{\circ} \mathrm{C}$ and $42^{\circ} \mathrm{C}$ respectively, ST agar for Str. thermophilus and SF agar for enterococci at $42^{\circ} \mathrm{C}$ for two days. Representative colonies were collected according to their shape and colour. Isolates were purified by streaking two times on the respective isolation medium and temperature. The isolation of Bifidobacteria spp. were performed by enumerating coagulated samples on modified MRS broth ( MRS supplemented with sodium acetate $(10 \mathrm{gm} / \mathrm{L}), 0.5 \mathrm{~g} / \mathrm{L}$ L.cyctein and $\mathrm{pH}$ was adjusted to 5.4 by acetic acid) followed by streaking at the same medium and isolated as described before. 


\section{Identification of isolates:- \\ Phenotypic identification:-}

All isolates were microscopically examined for Gram stain reaction, cell morphology and cellular arrangement. Catalase activity was examined by adding drop of 3 percent hydrogen peroxide on a clean microscopic slide. A visible amount of bacterial growth was added with the inoculating loop. Both were mixed and observed for gas bubble production. Only Gram-positive and catalase-negative isolates were identified at species level.The production of carbon dioxide from glucose was carried out as follows, $0.5 \mathrm{ml}$ of the purified isolate was inoculated in $2 \mathrm{ml}$ medium (at $40-45^{\circ} \mathrm{C}$ ) after that $2 \mathrm{ml}$ water agar $(1.5 \%)$ was added as an agar plug, incubated at $37^{\circ} \mathrm{C}$ and observed for gas production after $24-48 \mathrm{~h}$. A control was carried out using positive culture for carbon dioxide production "Saccharomyces lactis N.C.Y.C. 571".

\section{Growth at $45^{\circ} \mathrm{C}$ and at $10^{\circ} \mathrm{C}$ :-}

The ability of isolates to grow at $45^{\circ} \mathrm{C}$ or at $10^{\circ} \mathrm{C}$ were carried out as follows, each isolate was inoculated in broth medium; MRS of lactobacilli and M17 for lactococci $(1 \%)$ and then incubated at $45^{\circ} \mathrm{C}$ or at $10^{\circ} \mathrm{C}$ for $48 \mathrm{~h}$. The growth was observed in the medium; the control was an un-inoculated tube and incubated under same condition.

\section{Growth in the presence of $6.5 \%$ salt?:-}

This test was limited to the lactococci only; salt tolerance was assessed after 3 days of incubation at $6.5 \% \mathrm{NaCl}$ in M17 broth.

\section{Growth in SF medium:-}

This test was limited to the lactococci, the growth of strains was assessed after $48 \mathrm{~h}$ of incubation in SF medium at $42^{\circ} \mathrm{C}$.

\section{Molecular Identification of Lactic Acid Bacteria Species:-}

The isolates that isolated from fresh samples only were subjected to their genotypic characterization using BOX and ERIC PCRs as described below:

\section{Reference strains and cultivation:-}

The reference strains were obtained from Institute National de Recherche Agronomique (INRA), Center National de Recherches Zootechnique Jouy- en Josas, France (CNRZ), American Type Culture Collection (ATCC) and (DSM) Deutsche Sammlung von Mikroorganismen. These strains had been previously characterized on the basis of microscopic examination, Gram staining and catalase reaction. Stock cultures were maintained at $-40^{\circ} \mathrm{C}$ in reconstituted skimmed milk plus $15 \%$ glycerol and working cultures will be prepared from frozen stocks through MRS or M17 broth.

\section{DNA Extraction:-}

For DNA extraction, $1 \mathrm{ml}$ of an overnight culture was added to a $1.5 \mathrm{ml}$ microcentrifuge tube and Centrifuged at $13,000-16,000 \times g$ for 2 minutes to pellet the cells. The supernatant was removed. DNA was extracted from cells pellet using Wizard Genomic DNA Purification Kit (Promega, Madison, USA) as described by its manufacture.

\section{Repetitive -Polymerase chain reaction:-}

The DNA concentration of each sample was adjusted to $25 \mathrm{ng} / \mu 1$ in a $25 \mu 1$ PCR mixture. Amplification was performed in a $25 \mu 1$ reaction as described by Mohammed et al. (2009) and Kŕǐžovă et al. (2008). The molecular sizes of the amplified DNA fragments were estimated by comparison to a $100 \mathrm{bp}$ DNA ladder (Promega, Madison, USA) and were photographed using polaroid film. The Rep profiles were processed using the Gel ComparII version 5.00 software (Applied Maths, Kortrijk, Belgium). Similarity coefficients for pairs of tracks were calculated by using Pearson product moment correlation coefficient and strains were grouped by using the unweighted pair group method with arithmetic average (UPGMA).

\section{Preparation of camel milk whey:-}

Ten $\mathrm{ml}$ of camel milk was centrifuged at $5000 \mathrm{xg}$ for $30 \mathrm{~min}$ at $10^{\circ} \mathrm{C}$ to remove fat components. Whey was obtained after acid precipitation of casein at $\mathrm{pH} 4.6$ by adding $1 \mathrm{ml}$ of $10 \%(\mathrm{v} / \mathrm{v})$ acetic acid and incubated at $37^{\circ} \mathrm{C}$ for $10 \mathrm{~min}$. Following it was neutralized $1 / 10 \mathrm{vol}$ of sodium acetate and centrifuged at $10.000 \mathrm{xg}$ for $5 \mathrm{~min}$ at $4^{\circ} \mathrm{C}$. The supernatant was then dialyzed for $48 \mathrm{hrs}$ and stored at $4^{\circ} \mathrm{C}$ until used. 


\section{Determination of total whey proteins:-}

Twenty-five $\mathrm{ml}$ of whey (that was naturalized previously by $1 / 10$ vol. of $1 \mathrm{M}$ sodium acetate) was added in a breaker. Then, $1 \mathrm{ml}$ potassium oxalate solution $(28 \%)$ and $0.25 \mathrm{ml}$ phenolphthalein $(2 \%)$ was added into the sample. After mixing, the solution was titrated against sodium hydroxide (N/7) until the pink color appeared and then $5 \mathrm{ml}$. of neutralized formalin solution $(40 \%)$ was added to disappear the pink color followed by second titration against $\mathrm{NaOH}$ (N/7) until a faint pink color appears again and the second reading was represented as protein $\%$.

\section{Resistance to whey of camel milk:-}

Two hundred millimeter of camel milk whey (that included $12.2 \mathrm{gm}$ of soluble whey protein) was added to $800 \mathrm{ml}$ MRS media. Then, $1 \%$ of lactic acid bacteria strains were inoculated in media supplemented with whey. The optical density was determined at $650 \mathrm{~nm}$ during 3,6 and 24 hours compared with control (supplemented media without bacterial inoculation).

\section{Results and Discussion:-}

\section{Identification of Lactic acid bacteria:-}

The isolation of LAB from natural source have always been the most powerful means for obtaining useful and genetically-stable strains for industry important products

\section{Pre-identification using morphological tests and biochemical reactions:-}

In the present study, fifty-eight isolates that including 41 isolates obtained from camel milk and 17 isolates were obtained from cow milk. Pre-identification of isolates of different camel's milk and cow's milk samples is illustrated in Tables (1-2).

Table1: Pre-Identification Results Of Strains Isolated From Raw Camel And Cow Milk Samples That Collected From Different Origins In Egypt

\begin{tabular}{|c|c|c|c|c|c|c|c|c|c|}
\hline Strain No. & Origin & $\begin{array}{l}\text { Gram } \\
\text { stain }\end{array}$ & Catalase & $\begin{array}{c}\text { Growth on } \\
6.5 \% \text { Salt }\end{array}$ & $\begin{array}{c}\text { Growth at } \\
10^{\circ} \mathrm{C}\end{array}$ & $\begin{array}{c}\text { Growth at } \\
45^{\circ} \mathrm{C}\end{array}$ & $\begin{array}{c}\mathrm{CO}_{2} \\
\text { production }\end{array}$ & $\begin{array}{l}\text { Growth on } \\
\text { SF media }\end{array}$ & Pre Identification \\
\hline $1 \mathrm{CM}$ & AM & + & - & - & + & - & - & - & Lactococcus \\
\hline $2 \mathrm{CM}$ & AM & + & - & - & + & - & - & - & Lactococcus \\
\hline $3 \mathrm{CM}$ & AM & + & - & - & + & - & - & - & Lactococcus \\
\hline $4 \mathrm{CM}$ & AM & + & - & & + & - & - & & $\begin{array}{c}\text { Lactobacillus } \\
\text { G.B }\end{array}$ \\
\hline $5 \mathrm{CM}$ & AM & + & - & & + & - & - & & $\begin{array}{c}\text { Lactobacillus } \\
\text { G.B }\end{array}$ \\
\hline $6 \mathrm{CM}$ & AM & + & - & - & - & + & - & + & Enterococcus \\
\hline $7 \mathrm{CM}$ & AM & + & - & - & + & + & - & + & Enterococcus \\
\hline $8 \mathrm{CM}$ & AM & + & - & - & - & + & - & + & Enterococcus \\
\hline $9 \mathrm{CM}$ & $\mathrm{HSH}$ & + & - & & - & + & + & & $\begin{array}{c}\text { Lactobacillus } \\
\text { G.C }\end{array}$ \\
\hline $10 \mathrm{CM}$ & $\mathrm{HSH}$ & + & - & & - & + & - & & $\begin{array}{c}\text { Lactobacillus } \\
\text { G.A }\end{array}$ \\
\hline $11 \mathrm{CM}$ & $\mathrm{HSH}$ & + & - & & + & - & - & & $\begin{array}{c}\text { Lactobacillus } \\
\text { G.B }\end{array}$ \\
\hline $12 \mathrm{CM}$ & $\mathrm{HSH}$ & + & - & & - & + & - & & $\begin{array}{c}\text { Lactobacillus } \\
\text { G.A }\end{array}$ \\
\hline $13 \mathrm{CM}$ & $\mathrm{HSH}$ & + & - & - & + & + & - & + & E. faecium \\
\hline $14 \mathrm{CM}$ & $\mathrm{HSH}$ & + & - & & & + & & & Bifidobacterium \\
\hline $15 \mathrm{CM}$ & $\mathrm{HSH}$ & + & - & - & + & - & - & - & Lactococcus \\
\hline $16 \mathrm{CM}$ & $\mathrm{HSH}$ & + & - & - & + & - & - & - & Lactococcus \\
\hline $17 \mathrm{CM}$ & KM & + & - & & - & + & + & & $\begin{array}{c}\text { Lactobacillus } \\
\text { G.C }\end{array}$ \\
\hline $18 \mathrm{CM}$ & KM & + & - & & - & + & + & & $\begin{array}{c}\text { Lactobacillus } \\
\text { G.C }\end{array}$ \\
\hline $19 \mathrm{CM}$ & $\mathrm{Hb}$ & + & - & & - & + & - & & $\begin{array}{c}\text { Lactobacillus } \\
\text { G.A }\end{array}$ \\
\hline
\end{tabular}

$\mathrm{CM}=$ camel milk, AM=EL Amrya ,HSH=Halayeb\&Shalteen , $\mathrm{KM}=$ King mayot,Hb=Halayeb, $\mathrm{EO}=\mathrm{G} . \mathrm{A}=$, $\mathrm{G} . \mathrm{B}=$, G.C $=$ 
Table1:-(cont.): Pre-identification results of strains isolated from raw camel samples.

\begin{tabular}{|c|c|c|c|c|c|c|c|c|c|}
\hline Strain No. & Origin & $\begin{array}{c}\begin{array}{c}\text { Gram } \\
\text { stain }\end{array} \\
\end{array}$ & Catalase & $\begin{array}{c}\text { Growth on } \\
6.5 \% \text { Salt } \\
\end{array}$ & $\begin{array}{c}\text { Growth at } \\
10^{\circ} \mathrm{C} \\
\end{array}$ & $\begin{array}{c}\text { Growth at } \\
45^{\circ} \mathrm{C} \\
\end{array}$ & $\begin{array}{c}\mathrm{CO}_{2} \\
\text { production }\end{array}$ & $\begin{array}{c}\text { Growth on } \\
\text { SF media } \\
\end{array}$ & $\begin{array}{c}\text { Pre } \\
\text { Identification } \\
\end{array}$ \\
\hline $20 \mathrm{CM}$ & KM & + & - & & - & + & + & & $\begin{array}{c}\text { Lactobacillus } \\
\text { G.C }\end{array}$ \\
\hline $21 \mathrm{CM}$ & KM & + & - & & + & - & - & & $\begin{array}{c}\text { Lactobacillus } \\
\text { G.B }\end{array}$ \\
\hline $22 \mathrm{CM}$ & KM & + & - & & + & - & - & & $\begin{array}{c}\text { Lactobacillus } \\
\text { G.B }\end{array}$ \\
\hline $23 \mathrm{CM}$ & KM & + & - & & + & - & - & & $\begin{array}{c}\text { Lactobacillus } \\
\text { G.B }\end{array}$ \\
\hline $24 \mathrm{CM}$ & KM & + & - & - & + & + & - & + & Enterococcus \\
\hline $25 \mathrm{CM}$ & KM & + & - & & + & - & - & & $\begin{array}{c}\text { Lactobacillus } \\
\text { G.B }\end{array}$ \\
\hline $26 \mathrm{CM}$ & EO & + & - & + & - & + & - & + & Enterococcus \\
\hline $27 \mathrm{CM}$ & EO & + & - & + & + & + & - & + & Enterococcus \\
\hline $28 \mathrm{CM}$ & EO & + & - & + & + & + & - & + & Enterococcus \\
\hline $29 \mathrm{CM}$ & EO & + & - & - & - & + & - & - & $\begin{array}{c}\text { Streptococcu } \\
s\end{array}$ \\
\hline $30 \mathrm{CM}$ & EO & + & - & - & + & - & - & - & Lactococcus \\
\hline $31 \mathrm{CM}$ & NS & + & - & & - & + & - & & $\begin{array}{c}\text { Lactobacillus } \\
\text { G.A }\end{array}$ \\
\hline $32 \mathrm{CM}$ & NS & + & - & & - & + & + & & $\begin{array}{c}\text { Lactobacillus } \\
\text { G.C }\end{array}$ \\
\hline $33 \mathrm{CM}$ & NS & + & - & - & - & + & - & - & $\begin{array}{c}\text { Streptococcu } \\
s\end{array}$ \\
\hline $34 \mathrm{CM}$ & NS & + & - & - & + & + & - & + & Enterococcus \\
\hline $35 \mathrm{CM}$ & NS & + & - & - & + & + & - & + & Enterococcus \\
\hline $36 \mathrm{CM}$ & NS & + & - & - & + & + & - & + & Enterococcus \\
\hline $37 \mathrm{CM}$ & MM & + & - & + & + & - & - & - & Lactococcus \\
\hline $38 \mathrm{CM}$ & MM & + & - & - & + & + & - & + & Enterococcus \\
\hline $39 \mathrm{CM}$ & MM & + & - & + & + & - & - & - & Lactococcus \\
\hline $40 \mathrm{CM}$ & MM & + & - & - & + & - & - & - & $\begin{array}{c}\text { Lactobacillus } \\
\text { G.B }\end{array}$ \\
\hline $41 \mathrm{CM}$ & MM & + & - & - & + & - & - & - & $\begin{array}{c}\text { Lactobacillus } \\
\text { G.B }\end{array}$ \\
\hline
\end{tabular}

$\mathrm{CM}=$ camel milk,KM= King mayot, $\mathrm{EO}=\mathrm{El}$ Omyed,NS= North Sudan, $\mathrm{MM}=$ MarsaMatrouhG.A=, G.B=, G.C=

Forty- one isolates of Gram positive and catalase negative of none starter lactic bacteria (wild strains) (NSLAB) were isolated from 14 samples of camel's milk and 17 isolates were isolated from 5 samples of raw cow's milk and 2 samples of Zabady. The isolates were differentiated according to their morphological and physiological characteristics into five genus of LAB as follow: Enterococcus, Lactococcus, Streptococcus, Lactobacillus and Bifidobacterium. Isolated lactobacilli were classified into 3 groups according to Kandler and Weiss, (1986); group A, (obligate-homofermentative), B (facultative-hetero-fermentative) and C (obligate-hetero-fermentative).

Pre-identification using morphological tests and biochemical reactions of different camel's milk and cow's milk samples is showed in Tables (3).

Table 3:-Pre-identification using morphological tests and biochemical reactions

Genus
Raw Camel milk
Cow milk (raw and fermented) 


\begin{tabular}{|l|c|c|}
\hline Lactobacillus , Group A & 4 & 5 \\
\hline Lactobacillus , Group B & 9 & 4 \\
\hline Lactobacillus , Group C & 5 & 1 \\
\hline Enterococcus spp. & 12 & 4 \\
\hline Lactococcus spp. & 8 & 2 \\
\hline Streptococcus spp. & 2 & 1 \\
\hline Bifidobacteria & 1 & 0 \\
\hline
\end{tabular}

The results obtained from camel's milk showed that Lactobacilli species (43.90\%) were divided to group A (22.22\%), group B (50\%), and group C (27.78\%).Enterococcus spp. isolates represented 29.27\%, whereas Lactococcus spp. represented 19.51\%. The remaining isolates were Streptococcus and Bifidobacteria that represented as $4.88 \%$ and $2.44 \%$ respectively. While the isolates of cow's milk were Lactobacilli species (58.82\%) that divided to group A (50\%), group B (40\%), and group C (10\%), .Enterococcus spp. isolates (23.52\%), Lactococcus spp.(11.76\%) and Streptococcus spp.( $5.88 \%)$.

According to research results, Enterococcus and Lactococcus genus seem to be dominating in camel's milk. Similar results on predominant cocci microorganisms of camel milk compared with other species' milk have been already reported by Ashmaing et al., (2009); Khedid et al., (2009); Rahman et al., (2009); Jrad et al., (2013); and Akhmetsadykava et al., (2015).

\section{Identification by rep-PCR fingerprints:-}

Fifty-eight isolates were further characterized to species and subspecies level using Rep-PCR technique using BOXA1R primer for LAB. Identification was based on similarity coefficients for pairs of tracks calculated by using Pearson correlation coefficient and strains were grouped by using the unweighted pair group method with arithmetic average. Based on phenotypic and biochemical characteristics, the pre-identified isolates that belonging to group A, group B and group C for Lactobacilli, Enterococcus, Lactococcus and Streptococcus for lactococci and Bifidobacteria were subjected to genotypic identification using Rep-PCR as shown in Figures (1-9).

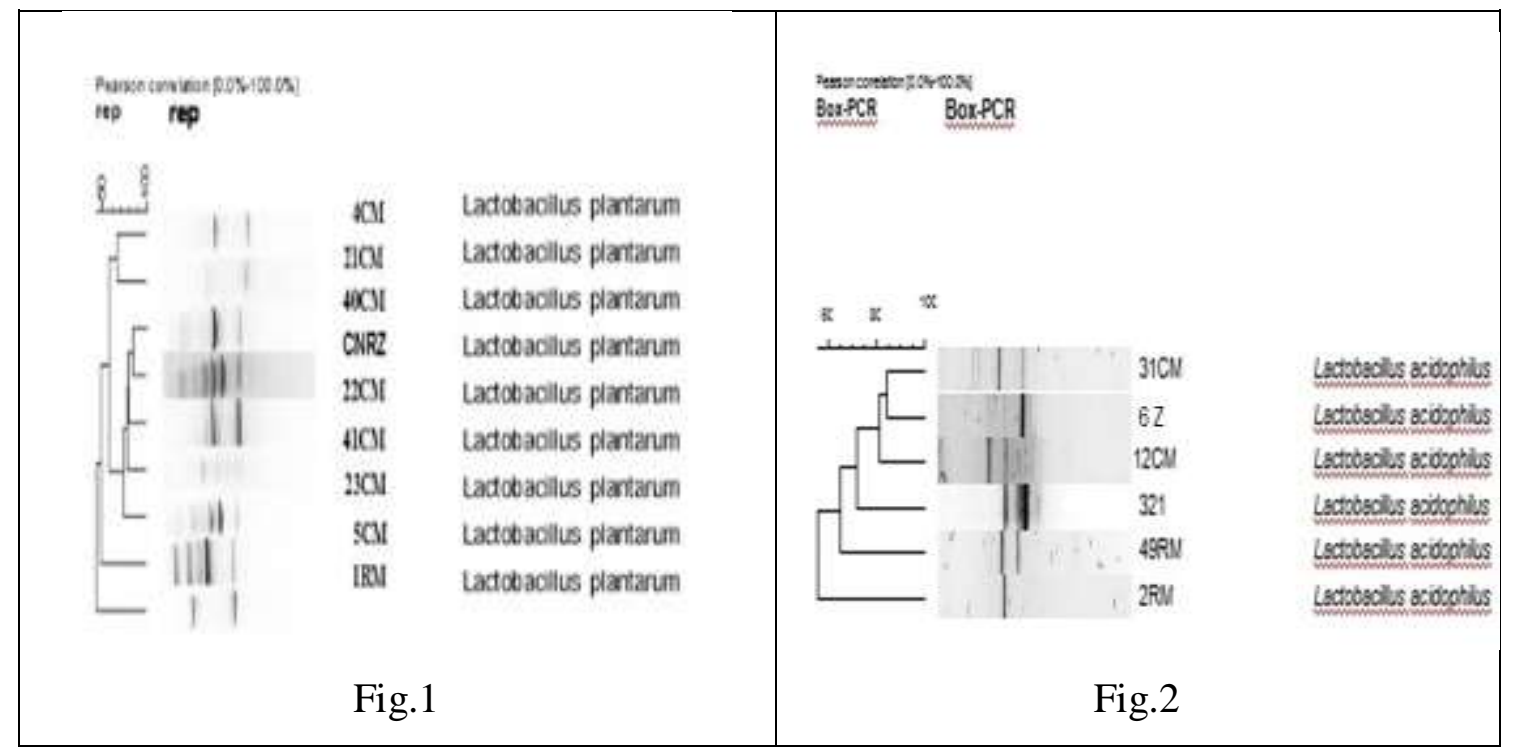




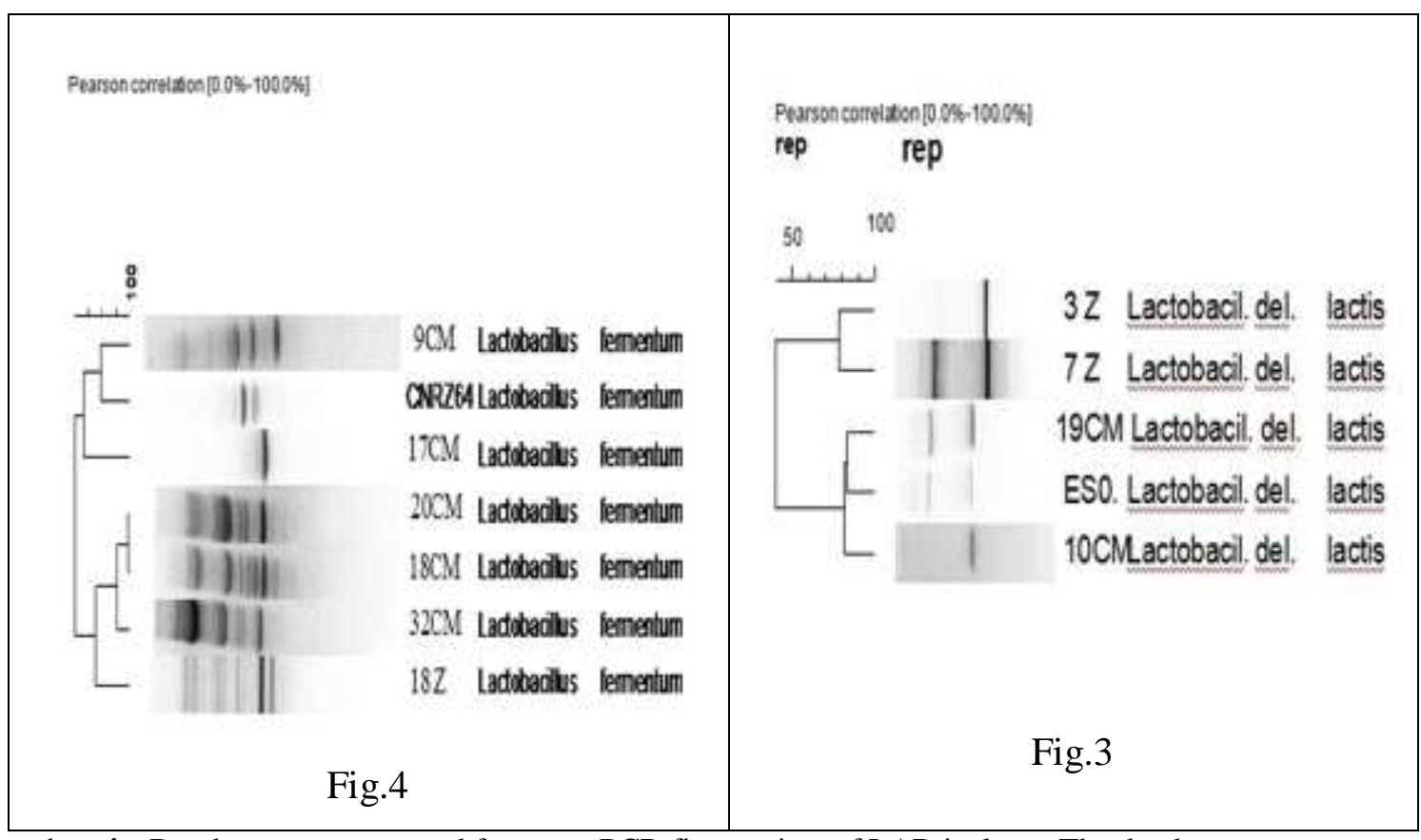

Figures 1 to 4:- Dendrograms generated from rep-PCR fingerprints of LAB isolates. The dendrogram was constructed using the unweighted pair group method using arithmetic averages with correlation levels expressed as percentage compared with reference strains of each species.

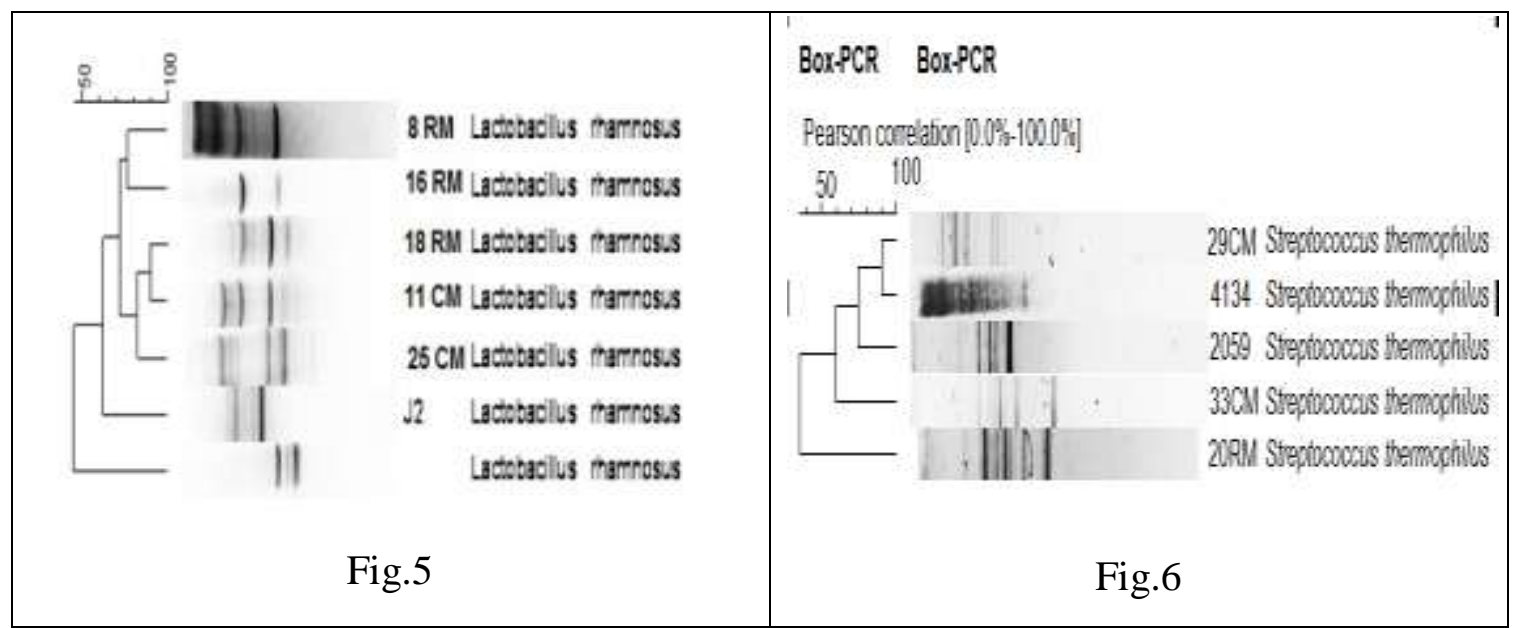




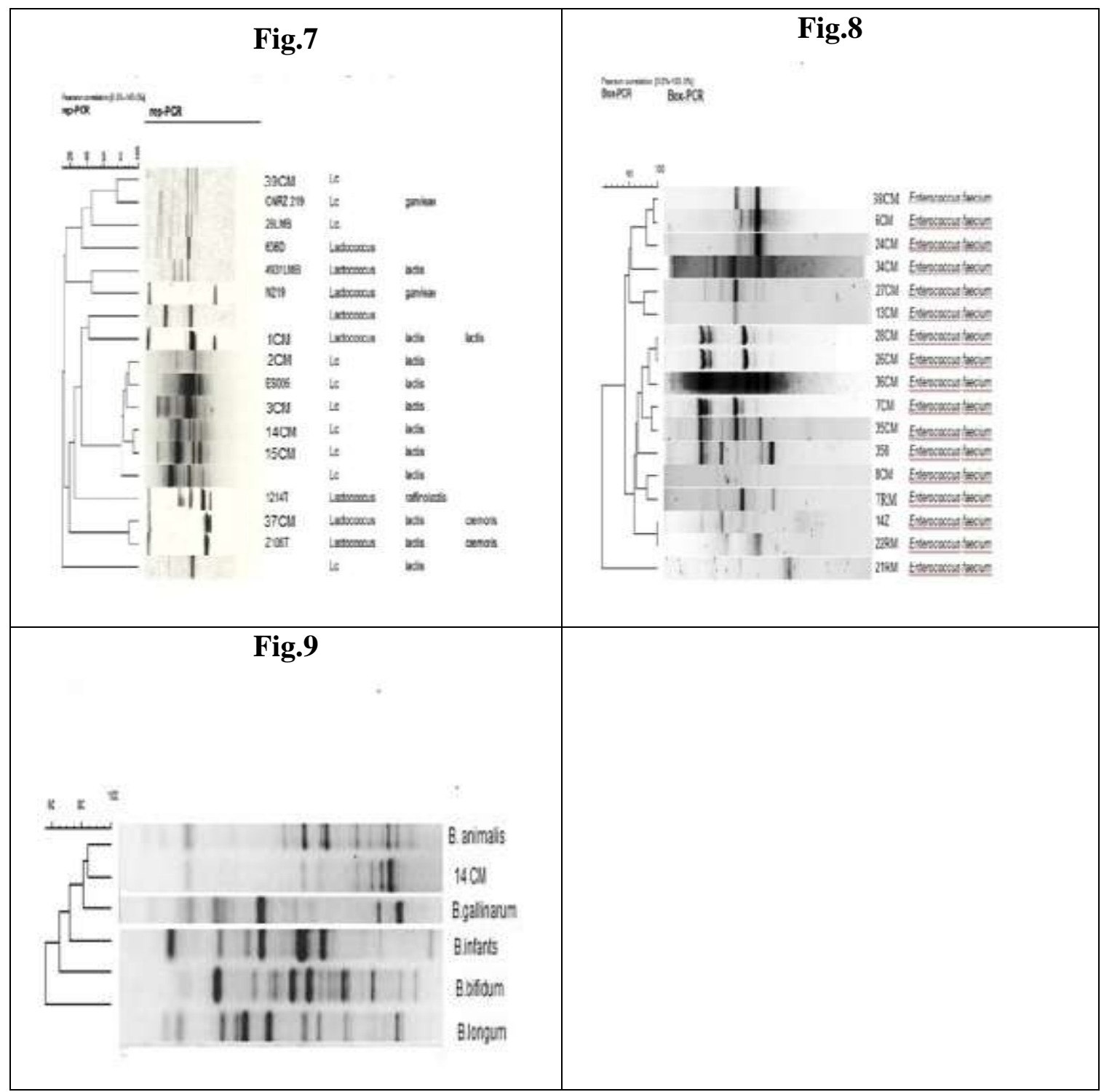

Figures 5 to 9:- Dendrograms generated from rep-PCR fingerprints of LAB isolates. The dendrogram was constructed using the unweighted pair group method using arithmetic averages with correlation levels expressed as percentage compared with reference strains of each species.

Figure (1) shows that seven isolates obtained from camel milk and one isolate obtained from cow milk were identified as Lactobacillus plantarum (Lb. plantarum) with similarity level $75 \%$ and $50 \%$ respectively comparing with CNRZ 5050 as a reference stain. On the other hand, two isolates obtained from camel milk and three isolates obtained from cow milk that were pre-identified as group A previously, were identified as Lactobacillus acidophilus (Lb. acidophilus) by Rep-PCR fingerprints at 75\% and 60\% similarity level respectively as shown in Figure (2), as well as, two isolates obtained from both camel and cow milks were identified as Lactobacillus delbrueckii subsp lactis (Lb. del. lactis) at similarity level $90 \%$ comparing with CNRZ 250 as a reference strain (Figure 3). Belonging to group C lactobacilli, five isolates from camel milk and one isolate from cow milk were identified as Lactobacillus fermentum (Lb. fermentum) with similarity level $85 \%$ and $80 \%$ respectively comparing with CNRZ64 as a reference strain (Figure4).

As illustrated in Figure (5) two isolates from camel milk and three isolates from cow milk were identified as Lactobacillus rhamnosus(Lb. rhmnosus) with similarity level 80\% comparing with the reference strain.

Twenty-nine from lactic acid cocci that were pre-identified previously as Lactococcus, Enterococcus and Streptococcus were distinguished by genotypic identification. All Streptococcus isolates ( 2 obtained from camel milk and one from 
cow milk) were clearly identified as Streptococcus thermophiles (Str. thermophiles) with a similarity level $60 \%$ comparing with DMS 20259 as a reference strain (Figure 6). Whereas six isolates from camel milk and two isolates obtained from cow milk were identified as Lactococcus lactis subsp. lactis (Lc. lactis.lactis) with similarity level 90\% compared with ES005 as a reference strain and two isolates obtained from camel milk only were identified as Lactococcus lactis subsp.cremoris (Lc. lactis cremoris) and Lactococcus garvieae (Lc. garvieae) that were detected for the first time in camel milk comparing with Z $105 \mathrm{~T}$ and CNRZ 219 as a reference strains respectively as described in Figure (7).

Among Enterococcus twelve isolates obtained from camel milk and four isolates obtained from cow milk were identified as Enterococcus faecium (En. faecium) using Rep-PCR amplification with similarity level 65\% comparing with CNRZ 131 as a reference stain (Figure 8). On the other hand, one isolate was identified as Bifidobacterium animalis (B. animalis) and represented as a minor species of LAB in camel milk (Figure 9). This result was in agreement with Savadogo et al.,(2004) who found detected Bifidobacterium species in traditional fermented camel milk and it represented $10 \%$ of LAB isolated from samples studied.

The percentage of LAB strains from camel and cow milks were illustrated at Table (4).

Table 4:- Distribution of lactic acid bacteria species isolated from camel's and cow's milk

\begin{tabular}{|c|l|c|c|}
\hline \multicolumn{1}{|c|}{ Species } & Number of isolates & \% of total isolates \\
\hline Lactobacillus & Lb. plantarum & 8 & 13.8 \\
\hline & Lb. acidophillus & 5 & 8.6 \\
\hline & Lb. fermentum & 6 & 10.3 \\
\hline & Lb. delbrueckii subsp. lactis & 4 & 7 \\
\hline & Lb. rhamnosus & 5 & 8.6 \\
\hline Lactococcus & Lc. lactissubsp.lactis & 8 & 13.8 \\
\hline & Lc. lactis subsp. cremoris & 1 & 1.7 \\
\hline & Lc. garviae & 1 & 27.6 \\
\hline Enterococcus & Enterococcus faecium & 16 & 5.2 \\
\hline Streptococcus & Streptococcus thermophilus & 3 & 1.7 \\
\hline Bifidobacteria & Bifidobacterium animalis & 1 & 100 \\
\hline Total & & 58 & \\
\hline
\end{tabular}

These results revealed that En. faecium was the dominant species in samples of camel and cow milks and represented 27.6\% of total isolates. These results were in agreement with Khadid et al., (2009); Hamed and El-Attar, (2013); Jrad et al.,(2013) who found that Enterococcus was predominant specie in camel milk samples collected from Morocco, Egypt and Tunisia respectively. Lactobacillus plantarum as well as Lc. lactislactis were predominant species with percentage 13.8 followed by $L b$. fermentum (10.3\%) of total isolates from both camel and cow milks. The remaining species including Lb. rhamnosus, Str. thermophilus, Lc. lactiscremoris, Lc. garvieae and B. animalis were detected as a sub dominant and minor species in both camel and cow milk as shown at Table (4). Thermophilic lactic acid bacteria such as Str. thermophilus and Lb. acidophilus were found in camel milk samples collected Halayeb and Shalateen and north Sudan and could not be detected in the remaining samples. This result was in agreement with Jans, Christoph, (2011) who found Str. thermophiles in camel milk collected from Kenya and Somalia, and Estiphano et al., (2016) who found the same results in raw camel's milk obtained from Ethiopia.

The obtained results revealed that Lc. lactis subsp. cremoris and Lc. garvieae that detected at the first time in camel milk were found in samples collected from Marsa matrouh governorate that located near the Mediterranean sea. The presence of this species in this sample of camel milk may be due to its high resistance to salt concentration as $L c$ garvieae always found in marine environment.

In this study the biodiversity of LAB obtained from camel milk from different regions in Egypt showed that noticed belonging to Lactobacillus acidophilus and Lb. del. lactis that could not be distinguished in camel milk samples obtained from north Egypt and found in samples collected from Halayeb and Shalateen and north Sudan, and this also was in agreement with Estiphano et al., (2016) who found the same species in raw camel milk from Ethiopia. These results may be due to the climate conditions in Sudan and east of Africa countries where high temperature encourages thermophilic bacteria to grow and become dominant LAB species in these regions. 
Our results regarding to the biodiversity of LAB isolated from raw camel milk were in agreement with many researchers who considered theses species of LAB isolated from raw camel's and cow milks and its traditional fermented dairy products. (Hamma et al., 1991; Isoro et al., 1994; Watabe et al., 1998; Yoneya et al., 1999; Nakamora et al., 1999; Mathara et al., 2004; Abdalla, 2007; Daimasso et al., 2008; Ashmaing et al., 2009; Khedid et al., 2009; Rahman et al., 2010; Hamed and El-Attar ,2011; Jrad et a., 2013; Manu and Adel, 2014; Akhmetsadykova et al., 2015 and Estiphano et al., 2016).

The ability to resist whey of camel milk:-

All LAB strains isolated from both camel and cow milks were tested to grow at constant concentration of whey camel's milk Figure (10).

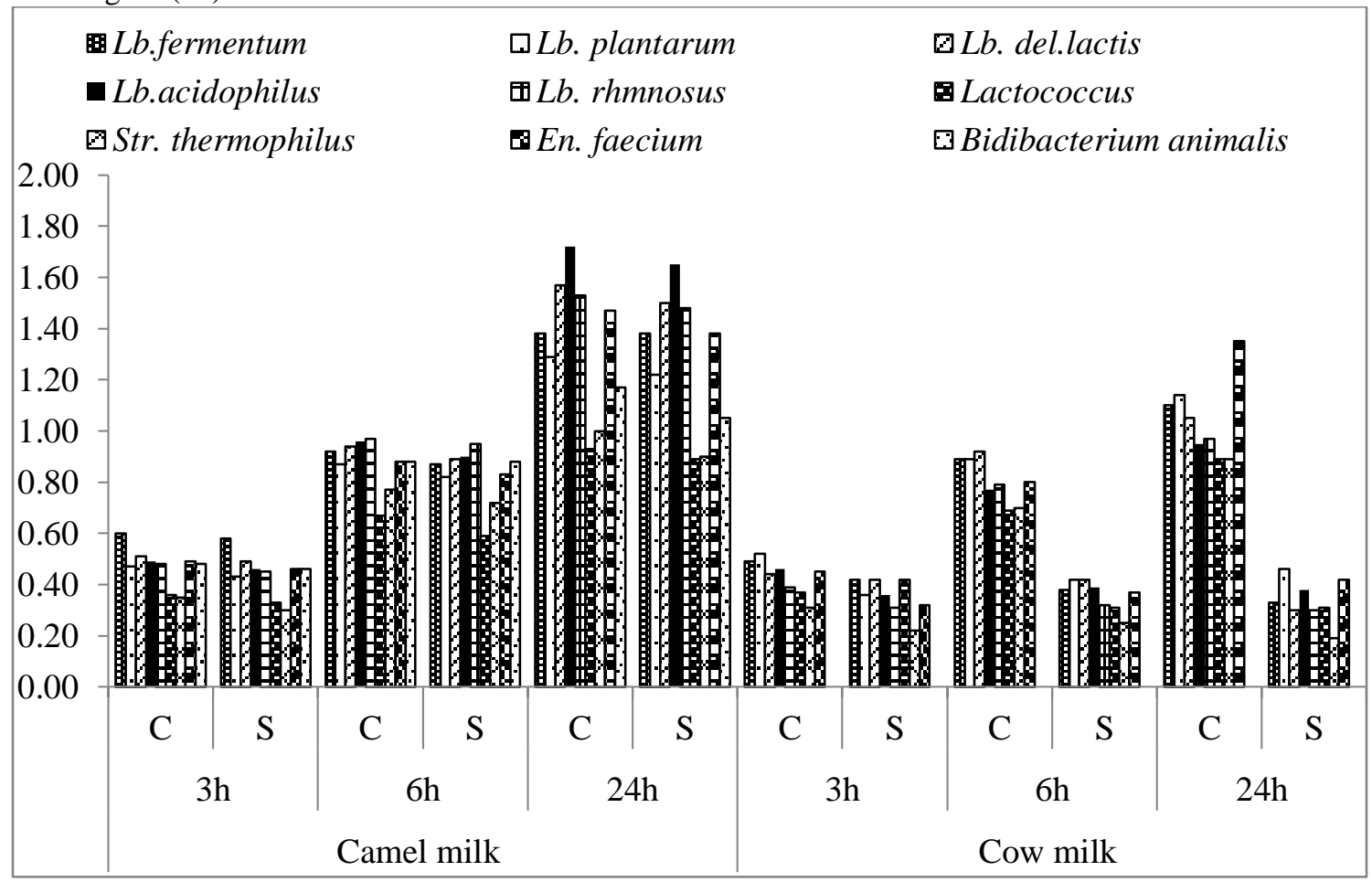

Fig.10:- Growth of LAB isolated from cow and camel milks expressed by optical density at 650nm during 24 hours of incubation comparing with control of each species.

interprets the averages of optical density values of bacterial growth at $650 \mathrm{~nm}$. The obtained results revealed that all LABS that isolated from camel's milk showed a good ability to grow at the $20 \%$ of camel milk whey during 24 hours compared with those isolated from cow milk. A gradual increase of bacterial growth was observed through 3,6 and 24 hours of incubation regarding LAB strains isolated from camel milk, whereas, a sharp decline was noticed of the growth of strains isolated from cow milk when examined to grow in cultures supplemented with whey. Camel milk strains belonging Lb.acidophilus, Lb. del. lactis and Lb. rhamnosus show the highest ability to resist the inhibition effect of Camel whey and there optical densities (O.D) were 1.65, 1.53 and 1.5 respectively after 24hrs of incubation comparing with the growth of the control ones. In contrast the same species that isolated from cow milks could not grow at this concentration of whey camel milk and their O.D was 0.38 for Lb acidophilus and 0.3 for Lb.rhmnosus comparing with control ones that recorded 0.95 and 0.97 respectively at the same time. The same behaviors were noticed on $L b$. fermentum and $L b$. plantarum isolated from camel milk that show a good ability to grow in the presence of camel whey and their O.D after 24hrs were 1.38 and 1.22 respectively comparing with control that examined to grow in media without camel whey. By comparison the same species that isolated from cow milks to grow in medium supplemented with whey, it is clear that cow milk $L b$. fermentum and Lb. plantarum could not resist the inhibition effect of whey proteins and its O.D was 0.33 for Lb.fermentum and 0.46 for Lb.plantarum, even so its controls recorded 1.1 and 1.14 for same strains respectively after $24 \mathrm{hrs}$ incubation. 
On the other hand, Lactococcus and Str.thermophilus strains show a less ability to grow through medium supplemented with camel whey as their O.Ds after 24 hrs were 0.9 and 0.89 comparing with controls one that recorded 0.93 for Lactococcus and 1 for Str.thermophilus.

Strains belonging to Lb. fermentum, Lb. plantarum and Lb. acidophilus were the highest resistant to whey followed by Lb.delbrueckii lactis, Str.thermophilus, Enterococcus and Lc.lactis respectively. Strains 14CM that identified as B.animalis and $39 \mathrm{CM}$ that identified as Lc.garvieae demonstrated a good ability two grow at this level of whey and the same species could not be isolated from cow milk in our study.

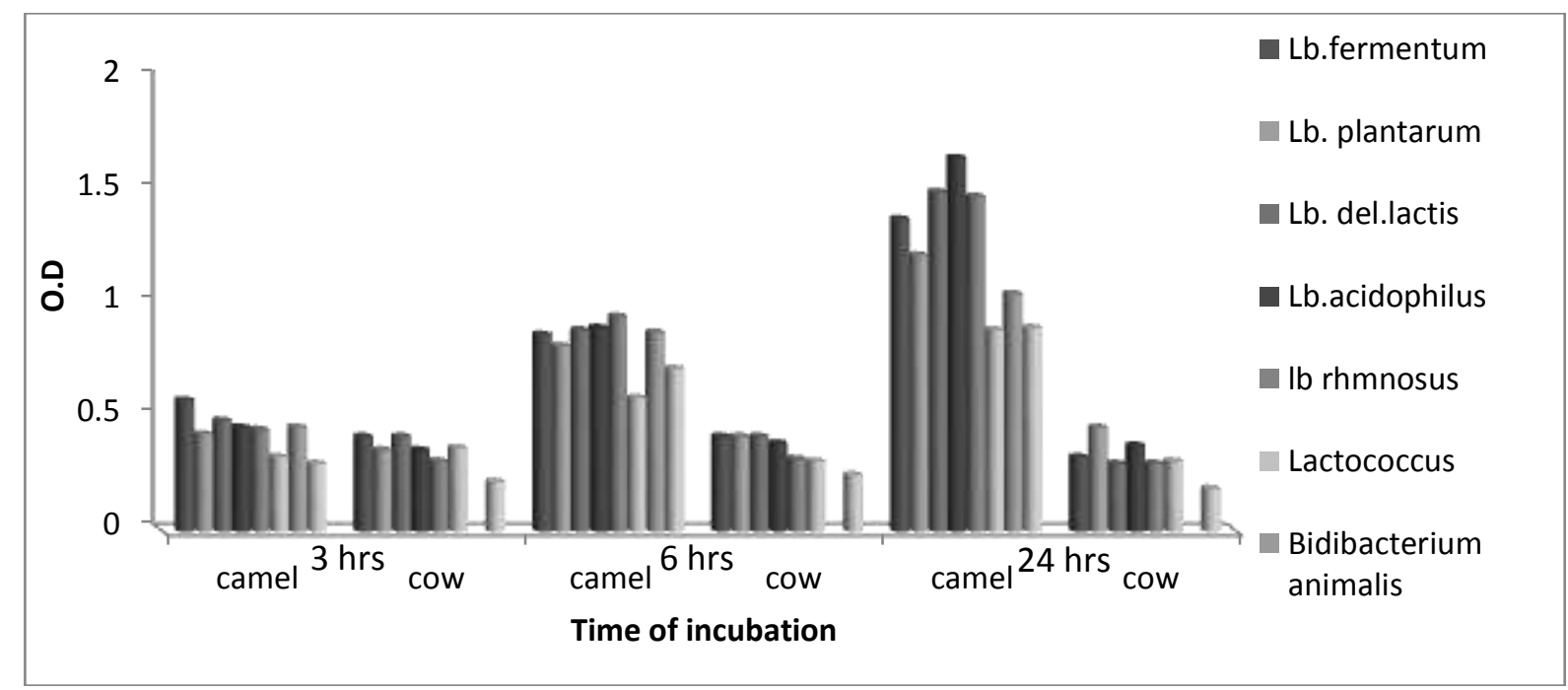

Fig.11:- Comparison the behaviors of LAB strains obtained from camel and cow milk during 24 hours of incubation.

Figure (11)illustrated the comparison of the bacterial growth between those isolated from camel and cow milks when it subjected to grow at the constant concentration of camel whey. Through the first three hours of incubation there were no significant differences between the growth of LAB strains obtained from cow and camel milks however, an evident differences were observed during the remaining 24 hours of incubation. After 6 hours of incubation LAB strains that obtained from camel milk grew increasingly whereas, the same species that obtained from cow milk could not able to progress and its optical density was almost constant. As represented in Figure (11) there is an apparent difference at the growth of LAB that obtained from the two sources. The optical density values of the bacterial growth after 24 hours of incubation established that LAB strains isolated from camel milk can grow optimally in the presence of camel whey at the same activity wherever it absence. In comparison with the behavior of same species of LAB that obtained from cow milk, it was noticed that cow milk LAB lost their activity and their growth declined sharply after 24 hours of incubation at the medium supplemented with camel whey.

As camel milk is rich in antibacterial proteins that control the growth of gram negative bacteria and peptidoglycan recognition protein which control the growth of gram positive bacteria and it could not detected in other Ruminants milk (Kappler et al., 2004), there is a need to examine the ability of LAB to resist the antibacterial effect of camel milk whey proteins.

Camel milk whey contains protective proteins such as serum albumin, lactoferrin, immune globulins and peptidoglycan recognition protein (PGRP) (Farah, 1993; Kappler et al., 2004; Marin et al., 2001).

According to Kappler et al. (2004) who detected that PGRP is found in camel milk only and the main role of this peptide is to control positive Gram bacteria and bound with peptidoglycan of the bacterial cell wall and thus inhibit LAB growth. Moreover, he reported that presence of exopolysaccharide (EPS) surroundings bacterial cell wall can avoid it from binding with PGRP. Based on these facts most of LAB isolated from camel milk should be EPS producers to save itself from the inhibition action of PGRP. This explanation is in agreement with Estiphano et al.(2016) who found that $85 \%$ of LAB isolated from camel milk had EPS production, and thus explain clearly the ability of LAB isolated from camel milk to resist its whey compared with those isolated from other sources such as cow milk. 


\section{Conclusion:-}

This study showed new aspects about the behavior of LAB isolated from camel milk that can grow in complicated ecosystem like camel milk and it resists the camel whey that rich in antibacterial proteins. In addition it is recommended that that these species should be further studied according to selection criteria for dairy industries like EPS production, acidifying activities and stimulation of immunological system and adhesion the epithelium tissue to can benefit from their unique characters to produce functional dairy products.

\section{Acknowledgments:-}

We acknowledge the financial support of Faculty of Agriculure- Alexandria University and Institute African research and studies for academic supports. The authors would to thank Prof.Dr Samir El Sheikh for his valuable assistance in providing camel milk Samples.

\section{References:-}

1. Abdalla, A.A. (2007). A study on the fermented camel's milk. Ph.D. Thesis, University of Al-Gezira, Sudan.

2. Abdel Rahman IE; Dirar and Osman MA, ( 2009). "Microbiological and chemical changes and sensory evaluation of camel milk fermented by selected bacterial starter cultures". African Journal of Food Science, 3, 398-405

3. Agrawal, R. P., Beniwal, R.; Sharma, S.; Kochar, D. K.; Tuteja, F. C. ; Ghorui, S. K.; and Sahani, M. S.( 2005). "Effect of raw camel's milk in type 1 diabetic patients: 1 year randomized study". Journal of Camel Practice Research. 12(1):27-35.

4. Akhmetsadykova S.H; Baubekova, A.; Konuspayeva, G.; Akhmetsadykov, N.; Faye, B, and Loiseau, G. (2015) African Journal of Food Science and Technology ((ISSN: 2141-5455) Vol. 6(3) pp. 84-88

5. Asres, A.and Yusuf, M. "Traditional Consumption, Therapeutic Value and Its Derived Dairy Products of Dromedary Camel (Camelus Dromedaries) Milk in Somali Regional State, Eastern Ethiopia" . Advances in Life Science and Technology. vol. 26, 2014, pp. 48:52.

6. Ashmaig, A., Hasan, A. and El Gaali, E. (2009). "Identification of lactic acid bacteria isolated from traditional fermented camel's milk (Gariss)" African Journal of mirociological Research. 3 (8), 451:457.

7. Carr, FJ., Chill D., and Maida, N. The lactic acid bacteria: a literature survey. Critical. Reviews in Microbiology (2002). $28: 281-370$.

8. Dalmasso, M., Prestoz, S., Rigobello, V., and Demarigny Y (2008). Evolution of the raw cow milk microflora especially lactococci enterococci leuconostocs and lactobacilli over a successive 12 day milking regime. Int. J. Dairy Sci. 3: 117-130

9. de Man, J.C., Rogosa, T. M. and Sharpe, E. (1960). A medium for the cultivation of lactobacilli. J. Appl. Bact. 23: 130.

10. Estifanos, H., Guesh,T., Kebede, A. and Menkir, S. (2016). Characterization of Lactic Acid Bacteria from Camel Milk and their Technological Properties to Use as a Starter Culture. East African Journal of Sciences 10 (1) 49-60.

11. Farah, Z., (1993): Composition and characteristics of camel milk, Journal of Dairy Research 60, 603-626.

12. Hamama, A. and Bayi, M. (1991): Composition and microbiological profile of two Moroccan traditional dairy products: RaibandJben; Journal of the Society of Dairy Technology.44 (4):118-120

13. Hamad, S. H. (2012). Factors Affecting the Growth of Microorganisms in Food. In Progress in Food Preservation. Edited by R. Bhat, . Alias and G. Paliyath. JohnWiley and Sons, Ltd. 405-428.

14. Hamed, E and El Attar, A. (2013) "Identification and Some Probiotic Potential of Lactic Acid Bacteria Isolated From Egyptian Camels Milk" Life Science Journal, 10 (1), 1953: 1961.

15. Hayek,S. and. Ibrahim, A. (2013). "Current Limitations and Challenges with Lactic Acid Bacteria: A Review". Food and Nutrition Sciences. 4, 73-87

16. Kandler, O. and Weiss, N. (1986). Genus Lactobacillus. Beijerink 1901, 212AL . In: Sneath, P. A., Mair, N. S., Holt, J. G. (Eds.), Brgys Manual of Systematic Bacteriology, Vol. 2. Wiliams and Wilkins, Batimore, MD, pp. 1209.

17. Khitam, A. (2003) "Camel milk plasma may help produce anti-microbial vaccine" Gulf News Al Nisr Publishing LLC

18. Kŕřžovă, J., Španovă, A., and Rittich, B. (2008) "RAPD and rep-PCR fingerprinting for the characteristization of Bifidobacterium species" Folia Microbiologica . 53 (2), 99-104.

19. Isono, Y., Shingu, I. and Shimizu, S. (1994): Identification and characterization of lactic acid bacteria isolated from Masai fermented milk in northern Tanzania. Bioscience-Biotechnology and Biochemistry. 58, (4): 660-664. 
20. Jans, Christoph, V. (2011). "Biodiversity of lactic acid bacteria in raw camel milk products of East Africa including genomic and functional characterization OF predominant lactose-adapted Streptococcus infantarius subsp. Infantarius" Doctoral Thesis, ETH Zurich, Research collection.

21. Jrad, Z.; El Hatmi, H.; Fguirl, I.; Arroum, S.; Assadi, M.; and Khorchan,i T. (2013). "Antibacterial activity of Lactic acid bacteria isolated from Tunisian came milk" African Journal of Microbiology Research. 7 (12), 1002:1008.

22. Kappeler SR.; Heuberger C.; Farah Z.; and Puhan Z (2004). "Expression of thepeptidoglycan recognition protein, PGRP, in the lactating mammary gland'. Journal of Dairy. Science. 87: 2660-2668

23. Khedid, K.; Faid, M.; Mokhtari. A.; Soulaymani, A.; and Zinedine, A. (2009). Characterization of lactic acid bacteria isolated from the one humped camel milk produced in Morocco. Microbiological Research 164: 81-91.

24. Lechiancole, T., Ricciardi, A. and Parente, E. (2002 ). "Optimization of Media and Fermentation Conditions for the Growth of Lactobacillus sakei,” Annals of Microbiology, Vol. 52, pp. 257-274.

25. Mertin, p.; pochart , P.; Flourie, B. ; Pellier, P.; and Santos , L .; and Desieg, M. (2001) . Effects of chronic ingestion of fermented diary product containing Lactobacillus acidophilus and Bifidobacteriumbifidum on metabolic activates of colonic flora in humans . American .Journal of Clinical Nutrition. 52 :685- 688.

26. Mathara, J.M., Schillinger, U., Kutima, P.M., Mbugua, S.K. andHolzapfel, W.H. (2004): Isolation, identification and characterization of the dominant microorganisms of kule naoto: the Maasai traditional fermented milk in Kenya. International Journal of Food Microbiology. 94: (3, 1): 269-278.

27. Muna, A. and Adel, M. (2014) "Isolation of Lactobacillus Strains with propiotic potentials from camel's milk " African Journal of Microbiology Research, 8 (15), 1645-1655.

28. Mohammed, M.; Abd El-Aziz, H.; Omran, N.; Anwar, S.; Awad, S. and El-Soda, M. (2009) " Rep-PCR characterization and biochemical selection of lactic acid bacteria isolated from the Delta area of Egypt". International Journal of Food Microbiology . 128( 3), $417: 423$

29. Nakamura, T.; Sugai, M.; Ozawa, A.N.; Ariga, H.; Koaze, H. and Kiiyukia, C. (1999)' Microbiological properties of Maziwa lala, a Kenyan traditional fermented milk of Masai community; Milk Science. 48, (1): 9-14.

30. Pfeiler, E. A., and Klaenhammer, T. R. (2007). The genomics of lactic acid bacteria. Trends in Microbiology, 15, 546-553.

31. Rahman, N.; Xiaohong C; Meiqin, F.and Mingsheng, D. (2009). Characterization of the dominant microflora in naturally fermented camel milk shubat. World J. Microbiol. Biotechnol. 25: 1941-1946

32. Renner, E., Schaafsma, G. and Scott, K. J. (1989) "Micronutrients in Milk and Milk-based Food Products" . Elsevier Applied Science, London, UK, pp. 1-70.

33. Reiter, B., (1985.) The biological significance of the non-immunoglobulin protective proteins in milk: Lysozyme, lactoferrin, lactoperoxidase, xanthine oxidase. Developments in Dairy Chemistry 3:281-336.

34. Savadogo A.; Ouattara, CAT.; Savadogo PW.; Ouattara AS.; Barro, N.; and Traoré, AS. (2004). "Microorganisms Involved in Fulani Traditional Fermented Milk in Burkina Faso." Pakistan Journal of Nutrition.3,134-139

35. . Singh, R. S. Ghorui, K. and Sahani. M. S. ( 2006)."Camel's milk: Properties and Processing Potential", In: M. S. Sahani (Ed.) pp. 59-73. The Indian Camel. NRCC, Bikaner.

36. Singh, M. B.;Lakshminarayana, J. and Fotedar. R. ( 2009). Nutritional status of adult population of Raika community in Jodhupur desert district of Rajasthan. J. Hum. Ecol. 26(2):77-80.

37. Song, D.; Ibrahim, S.; and Hayek, S. (2012). "Recent Application of Probiotics in Food and Agricultural Science', In: E. C. Rigobelo, Ed., Probiotics, InTech, Manhattan, 2012, pp. 1-34.

38. Watabe, J.; Ikeda, N.; Mizutani, J.; Sato, N.; Jin, s.; Hirai, T.; and Ariga, H. (1998): Comparison of microbiological and chemical characteristics among types of traditionally fermented milk in Inner Mongolia in China and Calpis sour milk (Sannyuu); Milk Science. 47, (1): 1-8.

39. Yoneya, T.; Nakajima, H.; Shimizu, K.; Miyamoto, T. and Kataoka, K (1999): "Isolation and characterization of lactic acid bacteria from Ergo (Traditional Ethiopian fermented milk)".Milk Science. 48, (2): 65-71. 